\title{
Complex concepts with varying connotations: In search for conceptual definitions*
}

\author{
I.V. Trotsuk \\ RUDN University \\ Miklukho-Maklaya St., 6, Moscow, 117198, Russia \\ Russian Presidential Academy of National Economy and Public Administration \\ Vernadskogo Prosp., 84, Moscow, 119571, Russia \\ National Research University - Higher School of Economics \\ Myasnitskaya St., 20, Moscow, 101000, Russia \\ (e-mail: irina.trotsuk@yandex.ru)
}

\begin{abstract}
One of the fundamental challenges for sociology is the interpretation of its key terms, which is determined by the fact that many words of everyday language and scientific discourse are the same despite implying a much higher level of generalization as sociological categories. Certainly, such challenges are more typical for the empirical research - when sociologists turn their theoretical concepts into sets of empirical indicators which have to be clear enough for the respondent to understand and answer the questionnaire and for the sociologist to interpret these answers correctly. Nevertheless, the lack of generally recognized conceptual definitions is no less important, because the general picture of social reality is necessarily made of them (the society is described as either fair, consisting of trustworthy institutions that provide opportunities for being happy, or in the opposite statements). The article presents a possible reconstruction of the strategy that sociologists use in the search for conceptual definitions for such complex concepts with varying connotations as love, happiness, trust and justice. This strategy consists of two steps: focus on the macro-sociological dimension of the phenomena under study as determining its various manifestations and everyday interpretations (the key step in the study of love and happiness); and identification of objective and subjective indicators of the phenomenon under study (the key step in the study of trust and justice). For instance, in the study of love and happiness, there is the obvious micro-sociological perspective that implies personal responsibility for being happy and loved, and the hidden macro-sociological perspective that implies social standards for identifying and achieving love and happiness; trust is defined as a source of social order, cooperation, institutional, organizational and everyday interactions, which reduces the level of uncertainty; in the searches for the conceptual definition of justice, there are two main approaches the first approach considers justice as one of many grounds for developing some theoretical model; the second approach reconstructs justice either as an 'ideal' political-philosophical model of social order or as a 'means' of the comparative analysis of its practical implementations.
\end{abstract}

Key words: complex concepts; varying connotations; conceptual definitions; love; happiness and (social) well-being; (social) trust; (social) justice; expert knowledge; social order

* C I.V. Trotsuk, 2021

The article was submitted on 25.02.2021. The article was accepted on 30.04.2021. 
We live in the discursively constructed world without focusing on the meaning of many words we use to communicate, to describe ourselves and others as unique creatures or typical representatives of social groups, and to explain social actions and phenomena. The words of everyday language and scientific discourse are often the same, despite scholars' efforts to achieve a higher level of generalization with special concepts and categories in order to exclude insignificant details and provide reliable explanatory models of social life. In sociology, this contradiction is determined mainly by the empirical research: in different types of surveys based on various techniques, we have to use questions that are clear enough to respondents to give answers in principle and within the set conceptual frame. Therefore, we cannot but ask people directly about trust, love, happiness or justice in some questions, even if most other questions are made of other words obtained after the empirical interpretation of the social phenomenon under study. Moreover, all four abovementioned words have many connotations, because we are used to thinking about ourselves, others and social life in general in terms of happiness (how happy we are and should be according to social standards), love (how love can be 'identified' and 'measured'), justice (why the world or people are unfair in general or to us in particular) and trust (what are criteria of social and interpersonal trust) referring to a variety of images constructed by the media, advertising, cinema, literature and works of art within different national traditions and models of mass culture.

Thus, the question is whether sociologists use some standard strategy for constructing conceptual definitions [see, e.g.: 41] for such complex concepts with varying connotations, which is the necessary first step in their empirical 'measurement'. Perhaps, there is a general path in the sociological search for 'legitimate' conceptual definitions of intangible and ambivalent 'objects' (taking into account that some social phenomena can be underrepresented to be worth studying, some can be tabooed, some are traditionally ignored as irrelevant/insignificant despite their acuteness in either sociological discourse or everyday life). The emphasis on the first step (focus on the macro-sociological dimension of the phenomena under study) on this general path is more typical for the sociological interpretation of more personally 'loaded' words (like love and happiness); while the emphasis on the second step (identification of objective and subjective indicators of the phenomenon under study) is more typical for the sociological interpretation of more socially 'loaded' words (like trust and justice) due to their greater importance for social control and order. Sometimes these steps are well represented in a specific book, but more often we need to reconstruct them from many works on different aspects of the social phenomenon under study.

A good example of the first step is the book by Illouz who defines sociology as "a study of collective forms of sufferings: inequality, poverty, discrimination, diseases, political oppression, large-scale armed conflicts, and natural disasters... Sociology has been very successful in analyzing these collective forms of suffering, yet has neglected the analysis of ordinary psychic sufferings that inheres in social relationships... If sociology is to remain relevant to modern societies, it must 
imperatively explore the emotions that reflect the vulnerability of the self in conditions of late modernity that is at once institutional and emotional" [25. P. 15]. Although the book describes love [see in more detail: 53], the same applies to happiness: there is the misery of both love (romantic pain) and unhappiness (despite objective well-being); there is the great transformation of both love and happiness as expressed in the changes of our will (how we want something), recognition (what matters for our self-esteem) and desire (what we long for and how); there is the marketization (penetration of marketing language and techniques into the realm of interpersonal relationships ) of both love and happiness [according to: 38] — the mass media sets criteria of attractiveness and worth for being loved and happy, because "sexuality, desire, and love [happiness] had become tightly intertwined with social stratification... and penetration of economics" [25. P. 58].

In the contemporary society, both love and happiness are increasingly considered a matter of personal choice, although it is as increasingly hard to make choices in the world of real and imagined options given our cognitive biases, 'information overload' and emotional delusions (we 'learn' fictional emotions through the identification with fiction and cinema characters and storylines). In the pre-modern times, "the center of gravity... referred to propriety, and strongly coded sex and gender conflict; today it focuses on the self disconnected from rank and defined by interiority and emotions; ... to be in love [happy] is to overcome a sense of ordinary invisibility, and entails a sense of uniqueness and an increased sense of self-worth" [25. P. 112, 113]. "Social worth is no longer a straightforward outcome of one's economic or social status, but has to be derived from one's self, defined as a unique, private, personal, and non-institutional entity. ...And modern social worth is chiefly performative: it is to be achieved in the course of and through one's interactions with others" [25. P. 119], which can make us both loved (rejected) and happy (miserable). Moreover, "pre-modern rationality involved little or no formal 'expert' knowledge... Contemporary actors from adolescence to adulthood develop an elaborate set of criteria for the selection of a mate and very sophisticated means to reach their goals [love and happiness - socially desirable and 'standardized' life goals]" [25. P.180]. Because the options and choices are numerous, changing and rationalized, we need 'experts' (from psychological counseling, divorce lawyers and non-fiction books to close friends or occasional anonymous friends in the Internet) to explain and 'teach' us what are our 'real' feelings and desires, what are true and achievable love and happiness, what are indicators of us having become loved and happy is we are not sure about our feelings and 'status'.

The searches for definition and acquisition of happiness and love went far beyond the limits of fiction that has always been involved in providing people with answers to questions on what happiness is and how to find love. Certainly, love is a less popular sociological issue than happiness the 'features' of which we can learn from international happiness rankings (combine statistical and survey data), national polls based on self-assessments (sometimes compare these assessments with objective indicators of well-being), and numerous articles, books, guides and 
courses providing recommendations on how to find happiness by 'leaving the comfort zone', changing the 'wrong' organization of one's life or learning to interpret it differently (happiness is declared a personal concern and responsibility [according to: 3]). The contemporary society ousts happiness from the macrosociological perspective by stressing that the possession of material and social benefits would not make one happy unless one is satisfied with oneself and one's life (either filled or not with the attributes of success). Moreover, everyday stereotypes of happiness do not always agree with its interdisciplinary interpretations. For instance, philosophical definitions emphasize the axiological essence of happiness as "the highest guiding principle or an ideal" [see, e.g.: 44. P. 25], psychological definitions - its positive emotional content as satisfaction and meaningfulness of life, acceptance of oneself and the world, and "full account of what happiness is" [see, e.g.: 46; 1. P. 9]; international comparative research projects - its social-economic indicators as no less important than selfassessments of well-being [see, e.g.: 6; 60; 61], and so on.

Thus, being as 'subjective' as love (due to the society's efforts to make them as 'personal' as possible), happiness is closer to trust and justice in its conceptual interpretations, because it has also turned into an 'umbrella term' implying a variety of criteria for assessing various aspects of social reality [see, e.g.: 56]. The specific combination of these criteria depends on our 'status' when assessing our life or general situation: as participants of everyday life (in the Schutzian perspective), we strive to live a happy life (as loving and loved people) in the society that provides us with opportunities, limitations and means for finding happiness (love); as representatives of other 'life worlds' (like sociological science), we strive to distance ourselves from everyday stereotypes of happiness in order to develop its conceptual definition and empirical indicators. Macro-sociological objective indicators (poverty, unemployment, housing conditions, etc. [see. e.g.: 6; 24; 60; 61]) and micro-sociological subjective indicators (life satisfaction, degree of loneliness, etc. [see, e.g.: $1 ; 8 ; 36 ; 42$ ]) of happiness can contradict: for instance, an increase in income does not necessarily determines an increase in the subjective well-being [see, e.g.: $12 ; 13 ; 29$. P. 15; 47. P. 362; 48. P. 153; 55].

Thus, there are two intertwined perspectives in the study of love and happiness: the obvious micro-sociological perspective that implies personal responsibility for being happy and loved, and the hidden macro-sociological perspective that implies social standards (reproduced by social institutions and discourses) for identifying and achieving love and happiness in general and for different genders, generations, other social groups and actors. "As Karl Marx famously put it, 'Human beings make their history themselves, but they do not do so voluntarily, not under circumstances of their own choosing, rather under immediately found, given and transmitted circumstances"' [25. P. 6]. The combination of these two perspectives in the study of complex concepts with varying connotations provides endless possibilities for the theoretical and empirical research. However, this combination obviously favors the macro-sociological perspective as emphasizing that personal choices provided 
by the contemporary society are illusionary: the society makes us believe in endless opportunities while creating many insuperable limitations (social rules and discourses impose specific scenarios on social milieus and society in general). The contemporary society overburdens us with musts even in our emotional life [22. P. 12] (macro-sociological perspective), and we develop strategies to cope with the social-cultural pressure (micro-sociological perspective) in order to find love and happiness. "What makes love [unhappiness] such a chronic source of discomfort, disorientation, and even despair can be adequately explained only by sociology, ... because the contents of thoughts, desires, and inner conflicts have an institutional and collective basis" [25. P. 12, 13].

The second step in the study of complex concepts with varying connotations is the choice of a combination of objective and subjective indicators, albeit often with an emphasis on the former and an ignorance of the latter. Thus, scholars recognize the ambiguity and complexity of the word 'trust' but often interpret it in a simplified way - as a kind of an invariable attribute of a special type of relationship between individuals, groups and institutions. In traditional societies, trust was based on social and moral imperatives, today it is rationally based on social-economic structures, i.e., trust is reproduced for a variety of purposes (for instance, in the theory of institutional economics, trust acts as an effective way to reduce transaction costs). This simple and convincing interpretation of trust reveals a paradox: if there is institutional trust, then there would be institutional distrust, and their ratio depends on the social-cultural situation in the specific country in the given historical period.

Sociology cannot claim exclusive rights in the study of trust due to its interdisciplinary [see, e.g.: 2. P. 208; 7]; therefore, sociological searches for its definitions rely on trust's political, anthropological, historical, economic and other interpretations [see, e.g.: 28]. Social sciences prefer to consider trust, on the one hand, through its origins and consequences in social life; on the other hand, through the factors and practical implications of different 'types' of trust - interpersonal [see, e.g.: 27; 49], organizational and institutional [see, e.g.: 31. P. 42-43, 62], spontaneous and voluntary, thoughtful and rational, cognitive, dispositional and moralistic, modern (trust is scattered among friends and colleagues and supported by formal systems of law, professional competences, etc.) and pre-modern (trust is concentrated in kinship systems, local communities and religious cosmology, which guarantee a sense of security, i.e., this is an idealized Tönnisian image of the community as a system with poorly differentiated formal connections but with strong social and personal ties based on loyalty and uniformity of values and morality) [see, e.g.: $17 ; 31 ; 32$. P. 49-50].

In the sociological tradition [see, e.g.: $16 ; 20 ; 50$ ], trust is defined as a source of social order, cooperation, institutionalization, organizational management, and everyday interactions [see, e.g.: 16. P. 95; 30. P. 667; 31. P. 20; see also: 26; 58]. Such a wide range of functions is determined by trust's unique ability to reduce the level of uncertainty [see, e.g.: 17; 50. P. 25, 115], although there are still debates about the determinants of this role of trust and about the forms of social interaction 
which can either strengthen trust or be reinforced by it. Nevertheless, this is a good conceptual interpretation of trust — it explains both the simplest everyday interactions and the most complex political, economic and social phenomena [see, e.g.: $9 ; 19 ; 21 ; 23 ; 34 ; 40]$. However, this does not mean that this interpretation implies a generally accepted system of empirical indicators [see, e.g.: 43; 45; 57; 59; 62]: in the survey, when respondents say that they trust the state, government, church, army or loved ones, they mean very different things just grouped under the term 'trust', but we ignore such semantic differences in order to obtain at least partially reliable and valid empirical data. This purposeful ignorance is justified by the emphasis on the objective - organizational and structural - factors and foundations of (dis)trust. For instance, behind various manifestations and practices of corruption (including clientelism), there are the same mechanisms - admiration for informal institutions, flexible networks and social capital, privatization of the public sphere, etc. [see. e.g.: 37].

Although the level of social trust is sometimes considered as determined by the level of social justice, the latter is also full of political connotations, socialeconomic meanings, and everyday interpretations (in the Schutzian perspective, justice is both a 'first-order construct' and a 'second-order construct') [see in more detail: 54]. According to Sztompka [50. P. 384], there are three levels of the idea of justice: (1) general moral principles that set socially recognized or desirable rules of behavior, (2) legal norms formalized in codes and laws, (3) implementation of these rules, norms and laws. The key difficulties in the sociological definition of justice are determined by the paradox: people think about justice mainly in the first interpretation, sometimes remember about the second one, while sociologists prefer to ask them about the third, i.e., our conceptual interpretations focus on justice as a macro-sociological category.

In the debates and searches for the general definition of justice as a macrosociological concept, there are two main approaches. The first approach considers justice as one of many grounds for developing some theoretical model. For instance, there is a functional-instrumental interpretation of justice as a value that supports a certain way of life; therefore, one can make a historical typology of societies that differ, among other things, by the types of inequality and violence that were acceptable as fair [33. P. 12-13]. There is a critique of this theory of justice as some objective state of social order, because the most exploited and oppressed classes can mistakenly believe in social justice of the absolutely unfair social order due to its rationalization or their delusions [14. P. 238].

Another example of considering justice as performing an auxiliary function in the social development is presented by "an ambitious and large-scale reconstruction of a pillar of the Western civilization - the coexistence of various forms of 'justice', i.e., those differences between legal and moral norms, between crime and sin, which made possible the idea of justice based on freedoms and guarantees" [39. P. 4]. To explain the current crisis of the globalizing world (crisis of the rule of law and erosion of the concept of justice), Prodi reconstructs the history of the 
West from the Middle Ages to the present day focusing on the $15^{\text {th }}-17^{\text {th }}$ centuries, when the codification of legal and ethical norms started and led to the dualism sin as disobedience to the moral law ('divine justice' based on reason) and crime as disobedience to the positive law ('human justice' based on reason and power).

For Prodi, the history of modernity is the gradual approval of a written norm, which eventually became a state monopoly and gave rise to a conflict between conscience (metaphysical natural-divine law based on the concept of sin) and law (changeable law of the state based on the concept of crime) due to the transition from the model of 'law is law for it is fair' to the model of 'law is law for it is established'. Discussions about the relationship between conscience and law (a mandatory set of rules) put an end to the legal pluralism of the medieval world and laid the foundation for modern ethics which obliged not only subjects to obey the sovereign (authority), but also the sovereign to respect the freedoms and rights of subjects. In the course of complex institutional and social-cultural transformations of the $17^{\text {th }}$ century, there was a transition from the moral theology of churches to the political-economic ethics of the $18^{\text {th }}$ century in search for a new legitimation of the norm. According to Prodi, morality was legalized through the criminalization of sin, law was moralized through the condemnation of civil and criminal lawlessness, and later the positive law became self-referential (combination of ideology, institutions and rituals).

Prodi insists that the contemporary world of a one-dimensional norm destroys the very idea of justice: "Justice supervises and punishes us for our sexual habits (reaching the point that manifestations of feelings are regulated by law and discussed in court), imposes new prohibitions, paralyzes family relationships, economic activity and work, health care and school education, and accompanies us from birth to death. ...Abortion and euthanasia, in addition to genetic manipulation and environmental protection, are the most striking manifestations of the inability of the one-dimensional norm to solve problems of justice... Protecting minorities or sectors of society considered weak with the help of special legal norms and courts, despite good intentions, also paralyze society just as 'political correctness' turns into dangerous censorship" [39. P. 505]. Thus, to achieve social justice, we need to return the gap between the legal norm and the collective moral norm (in Russia, this gap remains and is unlikely to disappear given the strengthening repressive measures of the state under the persisting informal types of social interactions).

In the second approach to the definition of justice, scholars strive to construct its 'ideal' political-philosophical model in order to make reasonable judgments on comparative justice with practical implications for the fight against injustice. Sen criticizes those theories of social justice that construct a model of an ideally fair social structure and reject a comparative analysis of social realities. According to Sen, in our daily lives we face various forms of inequality and oppression, but even famous historical figures did not try to create a perfectly fair society - only to eliminate as much injustice as possible [47. P. 11]. Sen believes that we need a theory of justice that would clarify rather possible approaches to strengthening justice and eliminating injustice than the nature of perfect justice - this theory 
would become a basis for practical reasoning by considering both institutional weaknesses and individual deviations as sources of injustice.

Sen develops his conceptual definition of justice by rejecting its three traditional interpretations: the definition of justice as fairness and the call for establishing the principles of justice by creating a social structure based on 'fair institutions' (Sen does not deny the role of institutions but emphasizes their instrumental nature); the search for perfectly fair social structures, which started during the Enlightenment (Sen opposes this search with a comparative method but supports the theory of 'social contract'); the interpretation of rationality and justice as exclusively European achievements of the Enlightenment (Sen shows that there were powerful traditions of reasoning and ideas of justice, honesty, responsibility, duty, kindness and rightness in the intellectual history of non-Western societies). Thus, Sen considers the comparative analysis a basis of justice, because public debates and reasoning guarantee some objectivity of political and ethical opinions, and argues that justice should be based on the idea of honesty in order to avoid biases in judgments and to respect interests and needs of others.

Sen reproduces the traditional sociological dilemma 'macro-micro' (institutions - behavior) by asking how the imaginary coherent and logical models of social contract ('people strive to ensure social justice by good deeds') can be achieved in our real world. Sen does not deny the importance of institutional equilibrium and its restraining function - he argues that we need institutions strengthening justice and should not consider 'right/fair' institutions as selfsufficient manifestations of justice [47. P. 130]. The study of social justice led Sen to the analysis of the relationship between happiness and well-being (determined by both social circumstances and subjective assessments). He does not agree with the idea that happiness is a criterion for assessing social justice, because there is a difference between well-being and happiness, on the one hand, and freedom and opportunities, on the other hand [see, e.g.: 29]. However, if we do not attribute a despotic determining role to happiness, it can rightfully be considered a very important factor, among other things (equality, freedom, etc.). Therefore, the main goal of all theories of justice is to make peoples' life better by helping them to fight injustice and by explaining their personal responsibility for protecting and strengthening justice by one's choices. This is a very difficult task for 'experts' that are expected to provide criteria for happiness, trust and justice (and their opposites), and this task has become even more difficult under the 'death of expertise' [35; see in more detail: 52].

Neither sociologists nor other social scientists have developed clear and reliable definitions of the phenomena that constitute the very foundations of our social life (love, happiness, trust and justice), despite numerous theoretical works and empirical research describing the society in the perspective of these phenomena (how happy we are and why, what types of love are important for us and why, whom we trust, and whether we believe in social justice). The lack of such conceptual definitions is so crucial, because the public prefers clear instructions on what to do 
and trusts government as relying on expert opinions. The covid-19 pandemic created not only the objectively new social-economic-political situation but also made us all personally responsible for difficult choices in the spheres we are not competent in and not capable of controlling the outcomes of our decisions [see: 3. P. 5; 15]. Certainly, we still trust doctors, lawyers and many others when we run into troubles, but we learn to use their "established knowledge as an off-theshelf convenience as needed and only so far as desired" [35. P. 4]. This worsens the traditional situation with the academic 'ivory towers' (experts retreat into scientific terminology and interact only with 'equals' in knowledge and rigor) and aggravates the scale of risks in the contemporary society [see; $5 ; 10]$, which leads to a general decline in social trust (to major social institutions based on expert knowledge [see: 18]), in social justice (not supported by social institutions), and, finally, in the very possibility of social happiness (if social institutions fail to provide necessary freedoms, opportunities and rules). Thus, ambiguous and confusing conceptual definitions undermine the very foundations of social order, which requires our efforts to more clearly describe the society we live in with the most essential social notions both experts and laypeople use [see: $4 ; 51]$.

\section{Funding}

The research was supported by the Russian Foundation for Basic Research. Project No. 20-011-00307 "Subjective and objective measurements of happiness: Justice as a criterion for personal and social well-being".

\section{References}

[1] Argyle M. The Psychology of Happiness. Saint Petersburg; 2003. (In Russ.).

[2] Bachmann R. At the crossroads: Future directions in trust research. Journal of Trust Research. 2011; 1 .

[3] Bauman Z. The Individualized Society. Malden; 2000.

[4] Bauman Z. Sociological enlightenment - for whom, about what? Theory, Culture \& Society. 2000; 17 (2).

[5] Beck U. Risk Society: Towards A New Modernity. London; 1992.

[6] Better Life Index. URL: http://www.oecdbetterlifeindex.org/ru/\#/11111111111.

[7] Brugger P. Trust as a discourse: Concept and measurement strategy. Journal of Trust Research. 2015; 5 (1).

[8] Chepurnykh M.N. Happiness indexes: Western experience (a sociological review). URL: http://www.teoria-practica.ru/-9-2012/sociology/chepurnykh.pdf. (In Russ.).

[9] Coleman J.S. Foundations of Social Theory. Cambridge; 1990.

[10] Doyle A. Trust, citizenship and exclusion in the risk society. URL: http://citeseerx.ist.psu.edu/ viewdoc/download?doi=10.1.1.610.6331\&rep=rep1\&type=pdf.

[11] Driver M. How trust functions in the context of identity work. Human Relations. 2015; 68 (6).

[12] Easterlin R. Income and happiness: Towards a unified theory. Economic Journal. 2001; III.

[13] Easterlin R. Will raising the income of all increase the happiness of all? Journal of Economic Behavior and Organization. 1995; 27.

[14] Elster J. Sour Grapes: Studies in the Subversion of Rationality. Moscow; 2018. (In Russ.).

[15] Flint J., Powell R. Individualization and social dis/integration in contemporary society: A comparative note on Zygmunt Bauman and Norbert Elias. F. Dépelteau, T.S. Landini (Eds.). Norbert Elias and Social Theory. New York; 2013. 
[16] Gambetta D. (Ed.) Trust: Making and Breaking Cooperative Relations. New York; 1988.

[17] Giddens A. Modernity and Self-Identity: Self and Society in the Late Modern Age. Cambridge; 1991.

[18] Giddens A. The Consequences of Modernity. Cambridge; 1990.

[19] Gorlizki Y. Structures of trust after Stalin. Slavonic and East European Review. 2013; 91 (1).

[20] Govier T. Social Trust and Human Communities. Montreal-London; 1997.

[21] Gudkov L. Trust in Russia: Meaning, Functions, Structure. Moscow; 2011. (In Russ.).

[22] Habermas J. The Philosophical Discourse of Modernity. Cambridge; 1990.

[23] Hosking G. Trust: A History. Oxford; 2014.

[24] Human Development Report. URL: http://hdr.undp.org/en.

[25] Illouz E. Why Love Hurts. A Sociological Explanation. Polity Press; 2016.

[26] Jalava J. Trust as a Decision. The Problems and Functions of Trust in Luhmannian Systems Theory. Helsinki; 2006.

[27] Kuchenkova A.V. Interpersonal trust in the Russian society. Sotsiologicheskie Issledovaniya. 2016; 1. (In Russ.).

[28] Lane C., Bachmann R. Trust Between and Within Organizations. Conceptual Issues and Empirical Applications. New York; 1998.

[29] Layard R. Happiness: Lessons from a New Science. Moscow; 2012. (In Russ.).

[30] Levi M. Sociology of Trust. Seattle; 2015.

[31] Luhmann N. Trust and Power. Chichester; 1979.

[32] Misztal B.A. Trust in Modern Societies. Cambridge; 1996.

[33] Morris I. Foragers, Farmers, and Fossil Fuels: How Human Values Evolve. Moscow; 2017. (In Russ.).

[34] Nannestad P. What have we learned about generalized trust, if anything? Annual Review of Political Science. 2008; 11.

[35] Nichols T. The Death of Expertise. The Campaign against Established Knowledge and Why It Matters. New York; 2017.

[36] Osin E.N., Leontiev D.A. Testing of the Russian-language versions of two scales for the expressassessment of subjective well-being. Materialy III Vserossiyskogo sotsiologicheskogo congressa. Moscow; 2008. (In Russ.).

[37] Papakostas A. Civilizing the Public Sphere: Distrust, Trust and Corruption. Moscow; 2016. (In Russ.).

[38] Polanyi K. The Great Transformation. Boston; 1944.

[39] Prodi P. A History of Justice: From the Pluralism of Forums to the Modern Dualism of Conscience and Law. Moscow; 2017. (In Russ.).

[40] Putnam R.P. Bowling Alone: The Collapse and Revival of American Community. New York; 2000.

[41] Riggs F.W. The importance of concepts: Some considerations on how they might be designated less ambiguously. American Sociologist. 1979; 14 (4).

[42] Rodionova L.A. Methodological aspects of measuring and modeling the level of happiness. Economika. Upravlenie. Pravo. 2012; 6. (In Russ.).

[43] Rothstein B. The Quality of Government: Corruption, Social Trust, and Inequality in International Perspective. Chicago-London; 2011.

[44] Rozanov V.V. The Purpose of Human Life. Moscow; 2001. (In Russ.).

[45] Sasaki M., Davydenko V.A., Romashkina G.F., Voronov V.V. Comparative analysis of trust in different countries. Sotsiologicheskie Issledovaniya. 2013; 3. (In Russ.).

[46] Seligman M.E.P. New Positive Psychology: A Scientific View of Happiness and Meaning of Life. Moscow; 2006. (In Russ.).

[47] Sen A. The Idea of Justice. Moscow; 2016. (In Russ.).

[48] Shmatova Yu.E., Morev M.V. Measuring the level of happiness: A review of Russian and foreign studies. Ekonomicheskie i Sotsialnye Peremeny: Fakty, Tendentsii, Prognoz. 2015; 3. (In Russ.). 
[49] Singh T.B. A social interactions perspective on trust and its determinants. Journal of Trust Research. 2012; 2 (2).

[50] Sztompka P. Trust: A Sociological Theory. Cambridge; 1999.

[51] Tabet S. Interview with Zygmunt Bauman: From the modern project to the liquid world. Theory, Culture \& Society. 2017; 34 (7-8).

[52] Trotsuk I.V. All power to the experts? Contradictions of the information society as both depending on and devaluating expertise. Russian Sociological Review. 2021; 20 (1).

[53] Trotsuk I.V. Some features of an inspiring book; or why sociologists should study love despite its intangibility. Russian Sociological Review. 2017; 16 (4).

[54] Trotsuk I.V. Justice in sociological discourse: Semantic, empirical, historical, and conceptual challenges. Russian Sociological Review. 2019; 18 (1). (In Russ.).

[55] Trotsuk I.V., Grebneva V.E. Possibilities and limitations of the key methodological approaches to the study of happiness. Vestnik Moskovskogo Universiteta. Seriya 18: Sotsiologiya $i$ Politologiya. 2019; 25 (3). (In Russ.).

[56] Trotsuk I.V., Koroleva K.I. Subjective well-being - quality of life or happiness? Gumanitarnye, Sotsialno-Ekonomicheskie i Obshchestvennye Nauki. 2020; 9. (In Russ.).

[57] Trotsuk I.V., Savelieva E.A. Comparative studies of value orientations: Potential, limitations, and the logic of development. RUDN Journal of Sociology. 2015; 4. (In Russ.).

[58] Tyler T.R. Trust and democratic government. V. Braithwaite, M. Levi (Eds.). Trust and Governance. New York; 1998.

[59] Uslaner E. The Moral Foundations of Trust. Cambridge University Press; 2002.

[60] Well-Being Index. URL: https://news.gallup.com/topic/well_being_index.aspx.

[61] World Happiness Report. URL: http://worldhappiness.report.

[62] Yamagishi T., Yamagishi M. Trust and commitment in the United States and Japan. Motivation and Emotion. 1994; 18.

\title{
Сложные понятия с множественными коннотациями: в поисках концептуальных определений *
}

\author{
И.В. Трощук \\ Российский университет дружбы народов \\ ул. Миклухо-Маклая, 6, Москва, 117198, Россия
}

Российская академия народного хозяйства и государственной службы при Президенте РФ просп. Вернадского, 82, Москва, 119571, Россия

Национальный исследовательский университет «Высшая школа экономики» ул. Мясницкая, 20, Москва, 101000, Россия (e-mail: irina.trotsuk@yandex.ru)

Аннотация. Одна из фундаментальных проблем социологического знания - определение своих основных понятий: многие слова повседневного языка и научного дискурса совпадают, несмотря на то что социологические категории предполагают более высокий уровень обобщения. Безусловно, проблема корректной интерпретации понятий более характерна для

* (С) Троцук И.В., 2021

Статья поступила в редакиию 25.02.2021 г. Статья принята к публикаичи 30.04.2021. 
эмпирической работы - когда социологи превращают свои концепты в наборы эмпирических индикаторов, которые должны быть настолько понятны респондентам, чтобы они смогли ответить на вопросы анкеты в заданных исследователем контекстуальных рамках, а социологи смогли сделать по результатам анализа этих ответов обоснованные выводы. Тем не менее, отсутствие общепризнанных концептуальных определений — не менее важная проблема, потому что наше представление о социальной реальности конструируется именно из них (мы считаем общество справедливым, состоящим из институтов, которым мы доверяем и которые обеспечивают нам возможности стать счастливыми, или же придерживаемся противоположных оценок). В статье представлена возможная реконструкция стратегии поиска концептуальных определений таких сложных понятий с множественными коннотациями, как любовь, счастье, доверие и справедливость. Эта стратегия включает в себя два шага: фокусировку на макро-социологическом измерении рассматриваемого феномена, поскольку именно это измерение определяет его разнообразные проявления и повседневные трактовки (в изучении любви и счастья этот шаг является основным); определение объективных и субъективных индикаторов рассматриваемого феномена (ключевой шаг в исследовании доверия и справедливости). Так, в социологическом анализе любви и счастья микро-социологическая трактовка очевидна (личная ответственность за то, чтобы обрести счастье и любовь), а ее макро-социологическая детерминация - не всегда (социальная стандартизация критериев обретения счастья и любви); доверие выступает источником социального порядка, сотрудничества, институциональных, организационных и повседневных взаимодействий, который снижает уровень неопределенности; в поисках концептуального определения справедливости можно выделить два основных направления - справедливость выступает (1) одним из множества оснований некоей теоретической модели общества, (2) «идеальной» политикофилософской моделью социального порядка или «инструментом» сравнительного анализа его разных версий.

Ключевые слова: сложные понятия; множественные коннотации; концептуальные определения; любовь; счастье и (социальное) благополучие; (социальное) доверие; (социальная) справедливость; экспертное знание; социальный порядок

\section{Информация о финансировании}

Статья подготовлена при финансовой поддержке РФФИ. Проект № 20-011-00307 «Субъективное и объективное измерения счастья: справедливость как критерий личного и социального благополучия». 